OPENING OF THE NEW LABORATORIES OF BACTERIOLOGY AND PUBLIC HEALTH OF KING'S COLLEGE, LONDON. $T$ HE completion of the arrangement by which primary and intermediate medical studies at Charing Cross Medical School are transferred to King's College, and the public health staff at King's College is attorded accommodation in their place, was marked on October $3^{\mathrm{I}}$ by the formal presentation of the laboratories by Prof. Simon Flexner, on behalf of the Medical School Committee, to the University of London, King's College.

Mr. H. A. Waterhouse presided, and in an introductory speech Dr. William Hunter, the Dean of Charing Cross, traced the development of the scheme, and suggested that the new laboratories would forward the ideal of Huxley, namely the progress of biological science.

Prof. Flexner expressed his pleasure at being present, for in so doing he considered that he would be helping the progress of public health, a science the knowledge of which is essential in all great cities, and especially in London. He spoke of the interest with which this science is regarded in America, and of the large sums of money given in order to forward research in that country, and expressed the hope that England, from whom America has learnt so much, might now follow her example in this respect.

The Hon. W. F. D. Smith (treasurer of King's College) expressed his agreement with Prof. Flexner's remarks, and said he was convinced that this day was a great one in the history of public health. He referred to the monumental skill and energy of Dr. Hunter, which had made the opening of the laboratories possible. The day, he argued, marked a stage in the policy of concentration which he was sure was a right one, as leading to a saving in labour and expense. The new laboratories would be used for research and for post-graduate teaching.

Dr. Headlam (principal of King's College) emphasised the advantages of this policy of reciprocity both to Charing Cross Hospital and to King's College. He supported a policy of concentration because he thought there was danger of money being squandered on new buildings which were not always needed. $\mathrm{He}$ reviewed the foundation of the Bacteriological Laboratory in 1887 by Dr. Edgar Crookshank, the first professor, and announced that Prof. Crookshank had presented his valuable library to the department. Their hope was that in time they would build up a fitting institute of hygiene within the University.

Sir Henry Miers (principal of the University) pointed out the need there was for willing cooperation of all available forces within the University, and held that Charing Cross and King's College had given a real example of what could and ought to be done in London.

The new laboratories and several structural and other improvements at the Charing Cross College were afterwards inspected by a large number of visitors.

\section{PROBLEMS IN INFECTION AND ITS CONTROL.}

$T$ HE Huxley lecture was delivered at Charing Cross Hospital (where Huxley studied) by Prof. Simon Flexner, director of the Rockefeller Institute, New York, who took as his subject "Some Problems in Infection and its Control."

After a reference to Huxley's work and to his Baltimore lecture in 1876 , the lecturer alluded to the fact that we are still ignorant of the causes of several important infective diseases, and after quoting the example of scarlet fever, proceeded to discuss the biological investigation of poliomyelitis, or infantile paralysis.

NO. 2245, VOL. 90]
Thrs disease occasionally occurs in epidemic and pandemic form, and arose in America in the Atlantic coast cities and other places which receive the emigrant population from Europe. On clinical grounds it had been regarded as infectious, but this remained uncertain until Landsteiner and Popper in 1909 found that it could be transmitted to monkeys by intraperitoneal injection of matter taken from the spinal cord of a fatal human case. This method of transmission is, however, an uncertain one, but if intracerebral inoculation be substituted, the disease is transmitted with certainty to monkeys. No parasite, bacterial or protozoan, can be detected in the diseased tissues microscopically, and it is found that the filtrate from an emulsion of the infected cord, filtered through a porcelain filter, is capable of infecting; the organism, therefore, is ultra-microscopic. Some eighteen diseases are now known the micro-parasites of which are ultramicroscopic or invisible with the best optical appliances; these include yellow fever, rabies, and vaccinia.

The virus of poliomyelitis is resistant to drying, light, and chemical action. Animals which recover from the disease are immune from a further attack. The poliomyelitis virus can be detected only in the central nervous system, in the mucous secretion of the nose and throat, stomach and intestine, and in the mesenteric glands-nowhere else. The virus probably gains access to the body by the nose and thence to the brain via the olfactory nerves. Carriers, either healthy and unaffected persons, or slight and abortive cases, exist, and serve to transmit the disease. It has been suggested that insects may help to spread the disease, but at present there is no evidence of this, though the virus remains active in the bed-bug for some days. Nor is there any evidence that the domestic animals spread the disease. Proof has been given that the sporadic (i.e. isolated or scattered) cases of infantile paralysis are caused by the poliomyelitis virus by the fact that the blood of these children contains the same immunising substances as are present in the epidemic form of the disease, and in inoculated monkeys. There appear to be biologically different strains of the poliomyelitis virus. Attempts have been made to devise a chemo-therapy for the disease, and urotropin, a drug which has some antiseptic action and is secreted into the cerebro-spinal fluid, has been found to be of some value in preventing infection exnerimentally.

\section{METEOROLOGY IN SCOTLAND.}

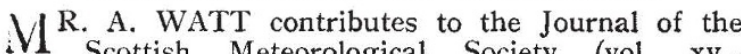
W Scottish Meteorological Society (vol. xv., rainfall of Scotland. The discussion is accompanied by a table giving for 594 stations the mean annual rainfall and the number of years used, and for 129 of the stations for which records for forty years were available the amount of the maximum and minimum annual rainfall and the years of their occurrence. 1872 appears to have been for Scotland, as for Great Britain as a whole, the wettest year, and 1887 the driest. A map showing the distribution of mean rainfall over Scotland, based upon the values given in the table, forms the frontispiece to the volume. The region of greatest rainfall is near to the west coast, north of the Caledonian Canal, where the width of the high ground from west to east is relatively small, so that east winds as well as west winds can contribute to the rainfall before they have precipitated their moisture on other mountain ranges.

Mr. Watt contributes also an interesting note on the early days of the society, from which we learn that the society was contributing meteorological reports to the Registrar-General for Srotland so long ago as 1856. We note also that for a short period in $185^{8}$ the late Prof. Everett was the secretary of the society. 